University of Nebraska - Lincoln

DigitalCommons@University of Nebraska - Lincoln

Transactions of the Nebraska Academy of

Sciences and Affiliated Societies

Nebraska Academy of Sciences

$10-20-2020$

\title{
Wetland edge trampled by American Bison (Bos bison) used as basking site for Painted Turtles (Chrysemys picta)
}

\author{
Keith Geluso \\ University of Nebraska-Kearney, gelusok1@unk.edu \\ Carter Kruse \\ Turner Enterprises, carter.kruse@retranches.com \\ Mary Harner \\ University of Nebraska at Kearney, harnermj@unk.edu
}

Follow this and additional works at: https://digitalcommons.unl.edu/tnas

Part of the Ecology and Evolutionary Biology Commons

Geluso, Keith; Kruse, Carter; and Harner, Mary, "Wetland edge trampled by American Bison (Bos bison) used as basking site for Painted Turtles (Chrysemys picta)" (2020). Transactions of the Nebraska Academy of Sciences and Affiliated Societies. 527.

https://digitalcommons.unl.edu/tnas/527

This Article is brought to you for free and open access by the Nebraska Academy of Sciences at DigitalCommons@University of Nebraska - Lincoln. It has been accepted for inclusion in Transactions of the Nebraska Academy of Sciences and Affiliated Societies by an authorized administrator of DigitalCommons@University of Nebraska - Lincoln. 


\title{
Wetland edge trampled by American Bison (Bos bison) used as basking site for Painted Turtles (Chrysemys picta)
}

\author{
Keith Geluso, ${ }^{1}$ Carter Kruse, ${ }^{2}$ and Mary J. Harner ${ }^{1,3}$ \\ 1 Department of Biology, University of Nebraska at Kearney, Kearney, Nebraska, 68849 USA \\ 2 Turner Enterprises, Inc., Bozeman, Montana, 59718 USA \\ 3 Department of Communication, University of Nebraska at Kearney, Kearney, Nebraska, 68849 USA
}

Corresponding author: Keith Geluso; 308-865-8982; email gelusok1@unk.edu

\begin{abstract}
Prairies of the Great Plains once were influenced by large-scale disturbances, such as fire and herbivory by large ungulates, that promoted ecosystem functioning. American Bison (Bos bison) created many types of disturbances as they traversed grassland landscapes. Trampling, a common type of bison disturbance, occurred when large herds moved through an area denuding aboveground vegetation, exposing prairie soils, and restarting succession. Bison reintroductions now allow researchers to use contemporary observations to examine influences of these large, hoofed mammals on system functions. Herein, we report on the immediate benefit of trampling along a wetland edge for another vertebrate species. We observed Painted Turtles (Chrysemys picta) basking in an area recently trampled by bison along a lake margin in the Sandhill Region of Nebraska. Basking generally is a thermoregulatory behavior for many species of pond turtles that optimizes physiological processes for individuals. Painted Turtles seldom leave the water except to nest, although they frequently bask on structures emerging from the water's surface or along the edge of shorelines, such as logs, Common Muskrat (Ondatra zibethicus) houses and platforms, and vegetational mats. A paucity of basking sites at this lake, along with dark, exposed soils near the water, likely facilitated this on-shore basking event on a mostly sunny, but cooler day. Reintroduction of American Bison to grasslands helps reestablish former interactions between biota and allows land managers and researchers to better understand how bison management in fenced ranches affects local fauna.
\end{abstract}

Keywords: American Bison, basking, Bison bison, Bos bison, disturbance, Nebraska, Painted Turtle, Chrysemys picta, Sandhill Region, trampling

DOI: $10.32873 /$ unl.dc.tnas.40.6

Prairies of the Great Plains of North America once were influenced by large-scale disturbances, such as fire, herbivory by large ungulates, or a combination of both, that promoted ecosystem functioning (Old 1969, Mack and Thompson 1982, Vinton et al. 1993, Samson and Knopf 1996, Knopf and Samson 1997, Johnson and Matchett 2001, Fuhlendorf et al. 2009). Large numbers of American Bison (Bos bison, hereafter bison) formerly roamed and grazed prairies of the Great Plains (England and DeVos 1969, Roe 1970, Moodie and Ray 1976, Shaw 1995). These large ungulates play important roles in grasslands through their direct and indirect effects on landscapes (Coppedge and Shaw 1997, Knapp et al. 1999, Johnson and Matchett 2001). Disturbances such as selective grazing, wallowing, fecal and urine deposition, death, and trampling are direct effects that promote plant species richness and diversity as well as spatial heterogeneity (Vinton et al. 1993, Hartnett et al. 1996, Hartnett et al.
1997, Knapp et al. 1999). Disturbances by large ungulates, native or domestic, also can positively affect prairie animals within these grassland systems (England and DeVos 1969, Matlack et al. 2001, Truett et al. 2001, Fuhlendorf et al. 2006, Engle et al. 2008).

Trampling, a common type of disturbance by bison, occurs when large herds move through an area, with the repetitive hoof action of many individuals removing vegetative biomass, exposing soils, and restarting succession (Soper 1941). These types of disturbances also can arise when individuals use the same area intensely, as with fenced reintroduced herds of bison or Domestic Cattle (Bos taurus) managed with high intensity, short-duration grazing or long-term overuse of an area by such ungulates. Trampling breaks rhizomatous grass mats that can regenerate from severed rhizomes, as such sod-creating grasses evolved with large ungulates (Mack and Thompson 1982). Limited information is known regarding the 


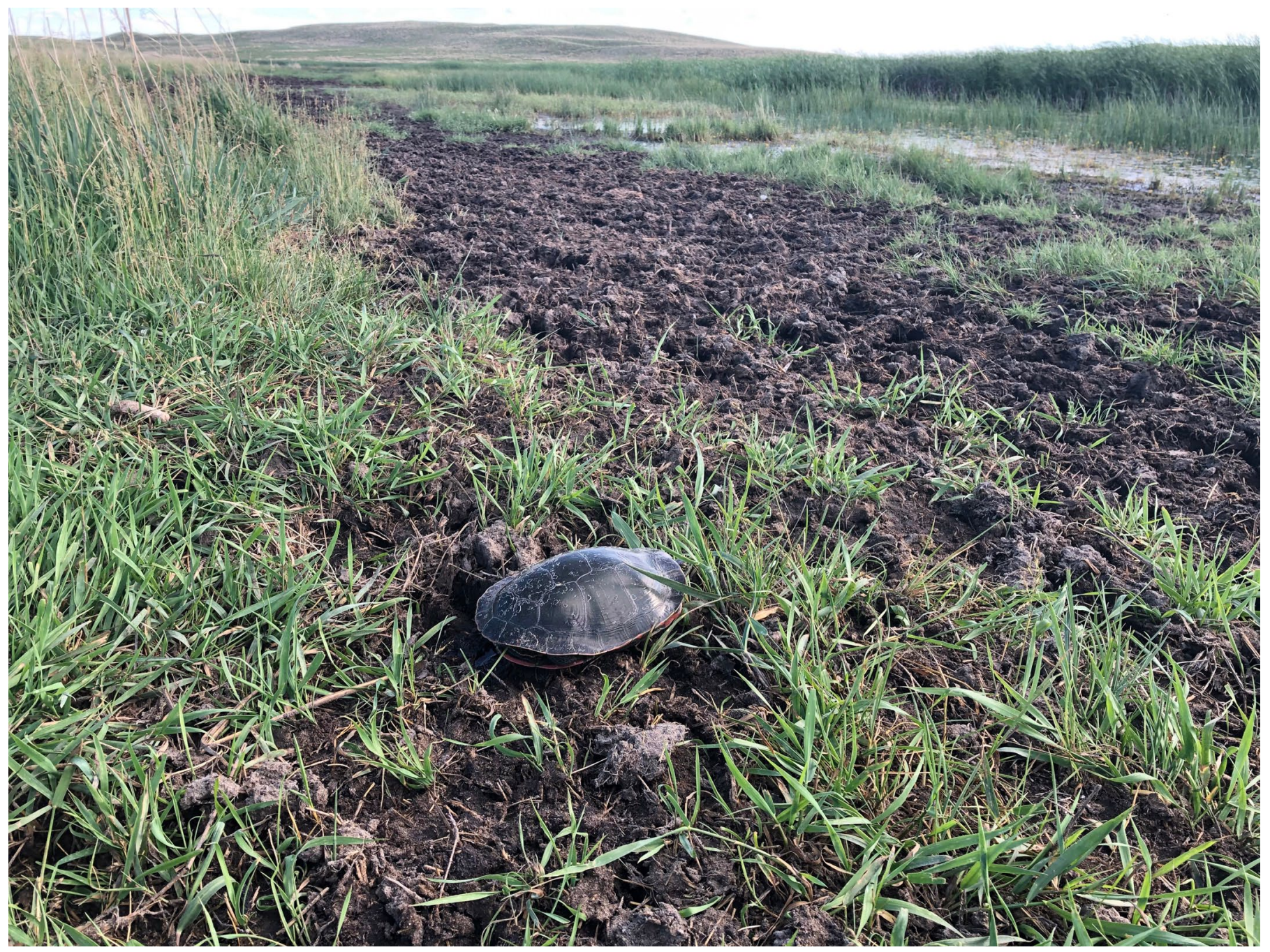

Figure 1. A Painted Turtle (Chrysemys picta) basking on a lake margin trampled by American Bison (Bos bison) in the Sandhill Region of Nebraska, Cherry County, on 18 June 2020. Photograph by K. Geluso.

effects of bison trampling on other biota. Herein, we documented use of an exposed wetland margin by Painted Turtles (Chrysemys picta) after trampling by bison on the McGinley Ranch, where the grass resource currently is managed with bison grazing.

Over $3.9 \mathrm{~km}$ of lake and wetland perimeters on the McGinley Ranch in Cherry County, Nebraska, were walked by a researcher on 18 and 19 June 2020 while searching for Common Muskrat (Ondatra zibethicus, hereafter referred to as muskrat) structures to learn more about turtles that bask on these structures in the Sandhill Region of Nebraska. From a distance, two motionless Western Painted Turtles (C. p. bellii) were observed on 18 June at 5:15 PM MDST, each at different locations near and not immediately adjacent the water's edge of Carpenter Lake in northwestern Cherry County $(2.9 \mathrm{~km} \mathrm{~N}, 12.3 \mathrm{~km}$ W Merriman; $42.94460^{\circ} \mathrm{N}, 101.94896^{\circ} \mathrm{W}$; NAD 83). Both individuals were within about a $200 \mathrm{~m}$ stretch of trampled land along the east side of the lake. The second turtle was photographed (Fig. 1), as both individuals appeared to be basking on the dark exposed trampled soils of the wetland margin. Both individuals were a few meters away from the water. Upon approaching, individuals voided bladder water. Once the researcher left the immediate area, both turtles headed towards the water. The daytime high was about $21.7^{\circ} \mathrm{C}$, breezy, and mostly sunny. No other turtles were observed while walking in and around wetlands during this trip to the ranch. 
Upon observing the basking turtles at the site, we sought to better understand why the site was trampled and to document characteristics of the trampled area. About 900 bison inadvertently entered the pasture (475 hectares) and were only there for two days before being moved back to the adjoining pasture from which they escaped (B. Davis, personal communication). Only this 200-m section of lake margin was trampled during this short time. Bison likely were attracted to the east side of Carpenter Lake due to the lush low-lying vegetation and location in the northernmost part of the pasture, as adults in this herd tend to move towards and congregate in the northernmost areas of pastures (B. Davis, personal communication). The trampled area was along the lake margin where flooding had occurred the previous year (2019) that was now dry. The area had low slope, sandy soils, and was situated between areas dominated by cattails (Typha) closer to the lake and uplands dominated by Switchgrass (Panicum virgatum). Due to the extent of grazing and trampling, we were unable to identify plants to species, but the area appeared to have been dominated by grasses, with some rushes (Juncus) and sedges (Carex). In 2020, bison appeared to prefer foraging in these drying wetland margins, concentrating activities in this lush band of vegetation lacking dead plant matter (J. Halstead, personal communication; K. Geluso, personal observation). As the dry summer progressed, we observed this phenomenon of trampling around other drying ephemeral wetland margins, as bison were rotated through other pastures. A return visit to Carpenter Lake later in the summer, when bison were present, demonstrated other wetland margins of this lake trampled. We suspect that our observation reflects bison activity concentrated in these drying, productive wetland areas rather than attraction to a specific plant species. With moist soils and the heavy weight of bison, these preferred sites subsequently were trampled. To our knowledge, these observations represent the first documentation of basking by a turtle species in areas trampled by American Bison.

Many groups of turtles bask, but members of the family Emydidae, in which Painted Turtles belong, are the most prominent (Boyer 1965). A number of studies discuss the importance of basking sites for turtles (e.g., Lindeman 1999, see references in Bodie 2001, Peterman and Ryan 2009). Basking is a common thermoregulatory behavior of turtles, although drying and reducing parasite loads also have been proposed as reasons for basking (Boyer 1965, Ernst and Lovich 2009). Maintaining temperatures within a specific narrow range for reptiles optimizes many physiological processes, such as rate and efficiency of digestion, energy acquisition, and reproduction (Hammond et al. 1988, Carriére et al. 2008). In an area with a short growing season, for example, female Painted Turtles basked longer than males during a time of year when females allocate energy to developing follicles, likely associated with increasing reproductive fitness (Carriére et al. 2008). Painted Turtles bask on any structure emerging from the water's surface as well as banks immediately adjacent of waterbodies (Ernst and Lovich 2009).

The limited basking structures, such as muskrat structures and floating logs, at this lake likely contributed, in part, to the use of the trampled area near the wetland margin. In general, the Sandhill Region of Nebraska lacks rocks and is not forested, with only some trees associated with permanent water (Bleed and Flowerday 1998). We observed some trees along the southern margin of the lake but did not observe floating or partially submerged woody debris on the east side of the lake. Although muskrats can be common in lakes of the Sandhills (Jones et al. 1983, Bleed and Flowerday 1998), few muskrat structures were present in 2020 on this ranch. We have observed that structures built by muskrats can be temporary and transient in large areas of open water in the western Sandhills, as thunderstorms and associated winds can completely remove such structures within minutes (K. Geluso and M. Harner, unpublished data). Additionally, muskrat populations are known to fluctuate greatly (Jones et al. 1983). Thus, the general lack of many basking structures in the water combined with dark exposed soils likely enhanced thermoregulatory properties of this basking site (Boyer 1965).

The trampled area was devoid of standing plant matter, which if present would block solar radiation. Turtles select unshaded basking sites, as sites with adjacent vegetation subject turtles to lower light intensities (Boyer 1965). Cattails surrounded the single muskrat structure observed on the eastern side of Carpenter Lake (Fig. 2). Additionally, the dark substratum likely promoted greater conduction than if basking on wood (i.e., floating logs, which we did not observe) or vegetative structures of muskrats (Boyer 1965). Basking also is possible while floating in water, but it is doubtful that enough of the turtle's body surface would be exposed to elevate body temperatures above water temperature by insolation (Boyer 1965).

Turtles generally bask in the morning and late afternoon, but individuals have been reported basking during 


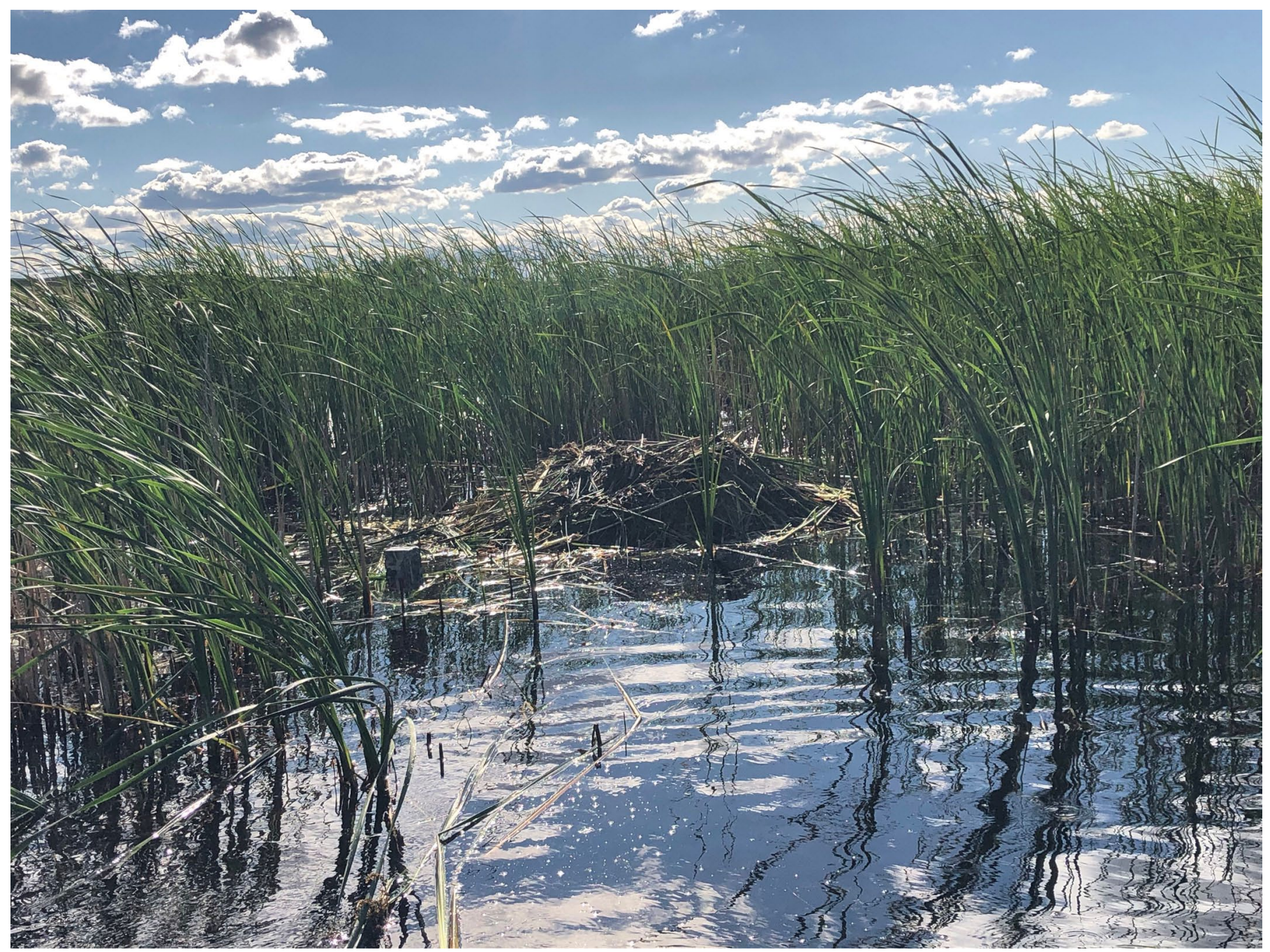

Figure 2. A Common Muskrat (Ondatra zibethicus) structure (center of photo) surrounded by cattails (Typha) on the east-southeast corner of Carpenter Lake on the McGinley Ranch, Cherry County Nebraska, 18 June 2020. This represented the only above water structure present on the eastern side the lake visible from the shoreline that would be available for basking by turtles. Photograph by K. Geluso.

all daylight hours (Ernst and Lovich 2009). The late afternoon observations reported herein correspond with a time when many individuals generally bask. Painted Turtles seldom move away from water bodies except to nest (Ernst and Lovich 2009). June is when most Painted Turtles nest in Nebraska, with most nesting forays beginning in the evening into the night (Iverson and Smith 1993). Some individuals migrate from shallow drying wetlands during summer (McAuliffe 1978). Although other explanations are possible why these two individuals were motionless on this trampled ground adjacent to a water body, it seems most parsimonious that individuals were basking.
Most trampling studies associated with large ungulates report on negative effects of this behavior, especially related to wetland or streamside habitats, with some studies conducted in non-grassland communities where large ungulates did not evolve within those systems (Bates et al. 2007, see Guthery and Bingham 1996, Jansen and Healey 2003). In grassland ecosystems, however, trampling behaviors also have positive outcomes. It is well understood that many grass species in prairies exhibit life history characteristics that are resilient to grazing and trampling, such as basal growth meristems and proportionately higher below-ground biomass and water storage (Mack and Thompson 1982). We do recognize 
that the movement of many large-bodied ungulates potentially will kill or harm smaller fauna species when stepped upon in the process of restarting succession and exposing soils. More research is needed to elucidate the benefits of trampling in grasslands, especially for faunal components. We made this observation in a pasture with bison, but similar intensive grazing by domestic livestock, such as Domestic Cattle, likely can have similar effects on lake edges, creating potential basking habitat for turtles. Prior herpetological studies in the Sandhill Region of Nebraska demonstrated that grasslands without grazing and fire resulted in lower diversity and abundance of herpetofauna (Ballinger and Jones 1985, Corn et al. 1995). Thus, we suspect there are unreported benefits of trampling behaviors by domestic and native ungulates in grassland systems. It is normal for bison to graze, wallow, and trample at different intensities across grassland landscapes, and in the process create a mosaic of vegetative types and elevates species diversity (Truett et al. 2001). Our study demonstrated that such a disturbance behavior can positively influence the behavior of another species in a grassland ecosystem.

Acknowledgments - We thank Turner Enterprises, Inc. for providing funding, housing, and the opportunity to study turtles in the Nebraska Sandhills. The Department of Biology at UNK assisted with logistical support. We thank Ben Davis and Chris Redman for field and logistical support on the ranch. We thank the reviewers for comments on an early version of this manuscript. These opportunistic observations of basking Painted Turtles occurred while seeking out Blanding's Turtles (Emydoidea blandingii) on McGinley Ranch in Cherry County.

\section{Literature Cited}

Ballinger RE and Jones SM. (1985) Ecological disturbance in a Sandhills prairie: impact and importance to the lizard community on Arapaho Prairie in western Nebraska. The Prairie Naturalist 17: 91-100.

Bates AJ, Sadler JP, and Fowles AP. (2007) Livestock trampling reduces the conservation value of beetle communities on high quality exposed riverine sediments. Biodiversity and Conservation 16: 1491-1509.

Bleed AS and Flowerday CA. (1998) An atlas of the Sand Hills. Resource Atlas No. 5, Conservation and Survey Division, Institute of Agriculture and Natural Resources, University of Nebraska-Lincoln.

Bodie JR. (2001) Stream and riparian management for freshwater turtles. Journal of Environmental Management 62: 443-455.

Boyer DR. (1965) Ecology of the basking habitat in turtles. Ecology 46: 99-118.
Carriére M, Rollinson N, Suley AN, and Brooks RJ. (2008) Thermoregulation when a growing season is short: sex-biased basking patterns in a northern population of Painted Turtles (Chrysemys picta). Journal of Herpetology 42: 206-209.

Coppedge BR and Shaw JH. (1997) Effects of horning and rubbing behavior by Bison (Bison bison) on woody vegetation in a tallgrass prairie landscape. The American Midland Naturalist 138: 189-196.

Corn PS, Jennings ML, and Bury RB. (1995) Amphibians and reptiles. In M.A. Bogan (Editor), A Biological Survey of the Fort Niobrara and Valentine National Wildlife Refuges, pp. 3259. (Fort Collins, Colorado: U.S. Department of the Interior, National Biological Survey)

England RC and DeVos A. (1969) Influence of animals on pristine conditions on the Canadian grasslands. Journal of Range Management 22: 87-94.

Engle DM, Fuhlendorf SD, Roper A, and Leslie Jr DM. (2008) Invertebrate community response to a shifting mosaic of habitat. Rangeland Ecology and Management 61: 55-62.

Ernst CH and Lovich JE. (2009) Turtles of the United States and Canada. 2nd Edition (Baltimore, Maryland: John Hopkins University Press).

Fuhlendorf SD, Engle DM, Kerby J, and Hamilton R. (2009) Pyric herbivory: rewilding landscapes through the recoupling of fire and grazing. Conservation Biology 23: 588-598.

Fuhlendorf SD, Harrell WC, Engle DM, Hamilton RG, Davis CA, and Leslie Jr DM. (2006) Should heterogeneity be the basis for conservation? Grassland bird response to fire and grazing. Ecological Applications 16: 1706-1716.

Guthery FS and Bingham RL. (1996) A theoretical basis for study and management of trampling by cattle. Journal of Range Management 49: 264-269.

Hammond KA, Spotila JR, and Standora EA. (1988) Basking behavior of the turtle Pseudemys scripta: effects of digestive state, acclimation temperature, sex, and season. Physiological Zoology 61: 69-77.

Hartnett DC, Hickman KR, and Fischer Walter LE. (1996) Effects of Bison grazing, fire and topography on floristic diversity in tallgrass prairie. Journal of Range Management 49: 413-420.

Hartnett DC, Steuter AA, and Hickman KR. (1997) Comparative ecology of native versus introduced ungulates. In F.L. Knopf and F.B. Samson (Editors), Ecology and Conservation of Great Plains Vertebrates, pp. 72-101. (New York, New York: Springer-Verlag)

Iverson JB and Smith GR. (1993) Reproductive ecology of the Painted Turtle (Chrysemys picta) in the Nebraska Sandhills and across its range. Copeia 1993: 1-21.

Jansen A and Healey M. (2003) Frog communities and wetland condition: relationships with grazing by domestic livestock along an Australian flood plain river. Biological Conservation 109: 207-219.

Johnson LC and Matchett JR. (2001) Fire and grazing regulate belowground processes in tallgrass prairie. Ecology 82: 3377-3389. 
Jones JK Jr, Armstrong DM, Hoffmann RS, and Jones C. (1983) Mammals of the Northern Great Plains (Lincoln, Nebraska: University of Nebraska Press).

Knapp AK, Blair JM, Briggs JM, Collins SL, Hartnett DC, Johnson LC, and Towne EG. (1999) The keystone role of Bison in North American tallgrass prairie. BioScience 49: 39-50.

Knoff FL and Samson FB. (1997) Ecology and conservation of Great Plains vertebrates. Ecological Studies 125. SpringerVerlag New York, New York, USA.

Lindeman PV. (1999) Surveys of basking map turtles Graptemys spp. in three river drainages and the importance of deadwood abundance. Biological Conservation 88: 33-42.

Mack RN and Thompson JN. (1982) Evolution in steppe with few large, hooved mammals. The American Naturalist 119: 757-773.

Matlack RS, Kaufman DW, and Kaufman GA. (2001) Influence of grazing by Bison and cattle on Deer Mice in burned tallgrass prairie. The American Midland Naturalist 146: 361-368.

McAuliffe JR. (1978) Seasonal migrational movements of a population of the Western Painted Turtle, Chrysemys picta bellii (Reptilia, Testudines, Testudinidae). Journal of Herpetology 12: 143-149.

Moodie DW and Ray AJ. (1976) Buffalo migration in the Canadian plains. Plains Anthropologist 21: 45-52.

Old SM. (1969) Microclimate, fire, and plant production in an Illinois prairie. Ecological Monographs 39: 355-384.
Peterman WE and Ryan TJ. (2009) Basking behavior of emydid turtles (Chysemys picta, Graptemys geographica, and Trachemys scripta) in an urban landscape. Northeastern Naturalist 16: 629-636.

Roe FG. (1970) The North American Buffalo: a critical study of the species in its wild state. $2^{\text {nd }}$ Edition (Toronto, Canada: University of Toronto Press).

Ross DA, Reaser JK, Kleeman P, and Drake DL. (1999) Rana luteiventris (Columbia Spotted Frog): mortality and site fidelity. Herpetological Review 30: 163.

Samson FB and Knopf FL. (1996) Prairie conservation: preserving North America's most endangered ecosystem (Covelo, California Island Press).

Shaw JH. (1995) How many Bison originally populated western rangelands? Rangelands 17: 148-150.

Soper JD. (1941) History, range, and home life of the northern Bison. Ecological Monographs 11: 349-412.

Truett JC, Phillips M, Kunkel K, and Miller R. (2001) Managing Bison to restore biodiversity. Great Plains Research 11: 123-144.

Vinton MA, Hartnett DC, Finck EJ, and Briggs JM. (1993) Interactive effects of fire, Bison (Bison bison) grazing and plant community composition in tallgrass prairie. The American Midland Naturalist 129: 10-18. 